\title{
Podatność osiedli wielkopłytowych z drugiej połowy XX wieku we Wroclawiu na procesy rewitalizacyjne
}

\author{
Robert Masztalski, Marcin Michalski
}

\begin{abstract}
Katedra Urbanistyki i Procesów Osadniczych, Wydział Architektury, Politechnika Wroctawska, e-mail:Robert.masztalski@pwr.edu.pl,marcin.michalski.arch@pwr.edu.pl
\end{abstract}

Streszczenie: W artykule prezentowana jest problematyka przekształceń wielkopłytowych osiedli z drugiej połowy XX wieku, wobec współczesnych potrzeb ich kompleksowej odnowy. Autorzy prezentują na wybranych przykładach, analizę urbanistyczną funkcjonujących kilkadziesiąt lat osiedli. Ulegają one stopniowej degradacji, zużyciu technicznemu, a ich zagospodarowanie przestrzenne odbiega od oczekiwań mieszkańców, zwłaszcza w dobie zmiany modelu społecznego. Analityczne podejście do problemu pozwoli ukazać stan zjawiska oraz predyspozycje, lub ich brak, do przekształceń w ramach działań rewitalizacyjnych.

Słowa kluczowe: osiedle, przekształcenia, rewitalizacja.

\section{Wprowadzenie}

Współcześnie osiedla mieszkaniowe stanowią strukturę urbanistyczną o zróżnicowanej historycznie zabudowie. Obecnie praktycznie nie ma inwestycji, które porównać można do wielkich założeń osiedli wielkopłytowych z lat 70. i 80. ubiegłego wieku, zarówno co do skali przestrzennej jak i kompleksowości założeń programowych. Powstająca nowa zabudowa stanowi najczęściej małe obszarowo „założenia”, realizowane bardzo często w niekompletnej strukturze istniejącej zabudowy mieszkaniowej. Działania inwestycyjne polegające na dogęszczaniu istniejących osiedli lub terenów przyległych do nich, są zjawiskiem powszechnym, także we Wrocławiu. [2] Wśród osiedli, w których mamy do czynienia z tym zjawiskiem, znajdują się wrocławski Gądów (tzw. Osiedle Kosmonautów) oraz osiedle Gaj. Oba te założenia mieszkaniowe cechuje podobny czas powstania, typ zabudowy a także struktura i program. Podobnie ma się rzecz w aspekcie dopełniania zabudowy i dogęszczaniu obszaru tych osiedli współczesną zabudową deweloperską. Analiza uwarunkowań urbanistycznych takich osiedli wskazuje na występowanie następujących problemów:

1. Istniejące, historyczne już, wielkopłytowe osiedla wielorodzinnej zabudowy mieszkaniowej, bazujące na urbanistycznych założeniach programowych z lat 70., wymagają działań modernizacyjnych i rewitalizacyjnych.

2. Powstająca w strukturze osiedli nowa wielorodzinna zabudowa mieszkaniowa oraz pojedyncze obiekty handlowo - usługowe, sytuowane są na wolnych od zabudowy terenach, bez wyprzedzającego zbilansowania zwiększających się potrzeb mieszkańców.

Rozbudowywane osiedla Gaj i Gądów, dogęszczane nowopowstającą zabudową mieszkaniowo-usługową, nie zapewniają tych potrzeb, które wynikają ze zmieniającego się modelu społecznego czy potrzeb cywilizacyjnych. Realizowana tam zabudowa mieszkaniowa zajmuje wolne przestrzenie, dogęszczając zabudowę, zwiększając gęstość mieszkaniową 
terenu oraz wykorzystując istniejącą infrastrukturę techniczną i społeczną. Skutkuje to ograniczeniem możliwości dostosowania funkcjonalno-przestrzennego osiedla w zakresie realizacji potrzeb mieszkańców, takich jak kreowanie atrakcyjnych przestrzeni wypoczynkowo-rekreacyjnych, czy też wystarczającej ilości bezpiecznych miejsc postojowych. Wymagające kompleksowych działań wielkie założenia osiedlowe wydają się tracić swoją szansę na szeroko rozumianą rewitalizację, której wymóg narzuca zarówno upływający czas, zużycie techniczne obiektów jak również zmieniający się model życia, rodziny i społeczeństwa. W obliczu powszechności występowania omawianego zjawiska, polegającego na tak zwanym dogęszczaniu osiedli wielorodzinnej zabudowy mieszkaniowej z końca XX wieku nową zabudową mieszkaniową, należy zwrócić uwagę na potrzebę ich pilnej i kompleksowej rewitalizacji.

\section{Uwarunkowania obszarów}

\subsection{Osiedle Gaj}

Osiedle Gaj znajduje się w południowej części Wrocławia, w Krzyckim Zespole Dzielnicowym, dawnej dzielnicy Krzyki. Obecnie określone jest administracyjnie granicami wytyczonymi: od północy - ul. Armii Krajowej, od wschodu - ul. Bardzką, od południa torami kolejowymi, od zachodu - ul. Spiską. Historycznie obszar osiedla obejmuje tereny miejscowości, która w 1904 roku została włączona do Wrocławia. Według źródeł dawna osada Gaj znajdowała się przy ul. Gajowej, pomiędzy ul. Kamienną a Proletariacką i zamieszkiwana była przez ludność polską (XVIII w.). Obecnie teren osiedla nie obejmuje obszaru dawnej osady. Pierwsze wzmianki o wsi Gaj pochodzą z 1304 roku.

Pod koniec drugiej wojny światowej, podczas oblężenia Wrocławia doszło do zniszczenia znacznej części osiedla. Z końcem lat 60. XX wieku osiedle charakteryzowało się ekstensywną zabudową, liczącą jedynie 249 domów mieszkalnych [1]. Pod koniec lat 70. rozpoczęła się budowa wielkopłytowego osiedla mieszkaniowego, docelowo według założeń projektowych dla 26 tysięcy mieszkańców. Budowa osiedla trwała do roku 1994. Pomiędzy ulicami: Armii Krajowej, Bardzką, Świeradowską i Borowską, zrealizowano jedynie połowę projektu konkursowego autorstwa Krystyny Chełmickiej, Kazimierza Oziewicza i Andrzeja Wolskiego [3]. Wybudowano wysoką, 12-kondygnacyjną zabudowę mieszkaniową w układzie zestawionych w linii łamanej bloków, tworzących półotwarte wnętrza z zielenią. Od zewnętrznej strony usytuowano ciągi komunikacji kołowej. W środkowej części założenia, bliżej ulicy Świeradowskiej, zrealizowano jednostkę szkolną w której mieści się szkoła podstawowa i gimnazjum. W latach 80 . XX wieku rozpoczęto budowę centrum handlowego, którą przerwano z przyczyn ekonomicznych, i dopiero po 2005 roku na bazie niedokończonego obiektu powstało centrum handlowo-usługowe Ferio-Gaj wg. projektu biura „Maćków Pracownia Projektów".

Na południe od ulicy Świeradowskiej znajduje się starsza, przedwojenna zabudowa jednorodzinna, oraz powstała z końcem lat 90-tych XX wieku i z początkiem XXI wieku niska wielorodzinna zabudowa mieszkaniowa. Zabudowa ta tworzy małe zespoły o układzie kwartałowym, z wyjątkiem zabudowy wypełniającej wolne przestrzenie w istniejącej, a zrealizowanej przed rokiem 1990 zabudowy.

1 Antkowiak Z., Stare i nowe osiedla Wroctawia. 

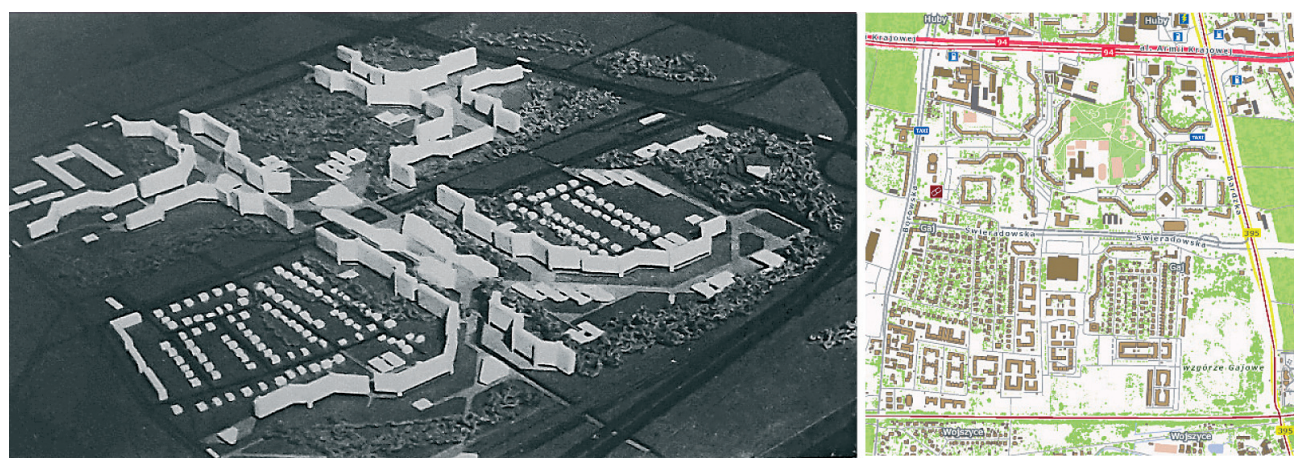

Rys. 1. Plan Osiedla Gaj z konkursu (1974 r.) - po lewej, (Źródło: 40 lat Miastoprojekt Wrocław: 1949-1989. Biuro Projektowo-Badawcze Budownictwa Ogólnego); Mapa osiedla GAJ (2016) po prawej: (źródło: http://gis.um.wroc.pl)

\subsection{Osiedle Gądów (tzw. Kosmonautów)}

Osiedle Gądów znajduje się w zachodniej części Wrocławia, w Gądowskim Zespole Dzielnicowym, dawnej dzielnicy Fabryczna, obecnie według podziału administracyjnego w obszarze Osiedla Gądów-Popowice Południowe. Analizowany teren ograniczony jest: od północy ulicą Lotniczą, od wschodu ulicą Na Ostatnim Groszu, od południa ulicą Bystrzycką i torami kolejowymi, a od zachodu ulicą Metalowców. Obszar pokrywa się z terenem historycznego Gądowa. [1]

Pierwsze wzmianki o Gądowie pochodzą z 1305 r. i mówią o istnieniu folwarku Gandow. W 1910 roku ówczesne władze zlokalizowały lotnisko, jako jedno z pierwszych w tym rejonie. Było ono w pierwszym okresie wykorzystywane głównie do celów wojskowych, a następnie przekształcono na cywilne. W 1928 roku Gądów został włączony do Wrocławia. Z końcem drugiej wojny światowej tereny uległy zniszczeniom w wyniku działań wojennych i przejęcia lotniska przez Armię Radziecką. Dawna zabudowa jednorodzinna, i wielorodzinna legła w gruzach, zaś Gądów przez lata pozostał niezainwestowany.
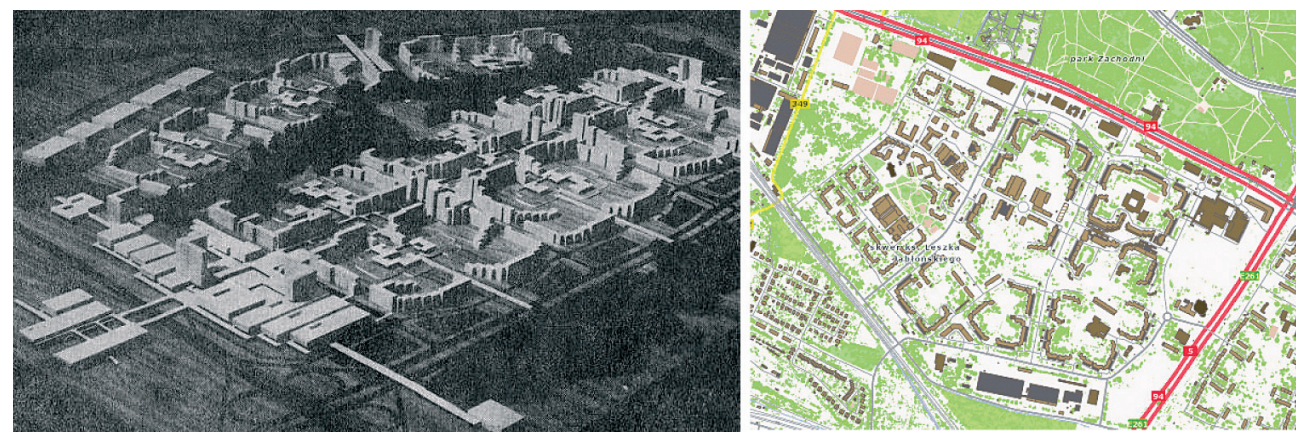

Rys. 2. Makieta osiedla Gądów z 1976 - po lewej (źródło: http://wroclaw.fotopolska.eu), mapa osiedla Gądów (2016) (os. Kosmonautów) po prawej (źródło: http://gis.um.wroc.pl) 
Z początkiem lat 70-tych ubiegłego wieku osiedle zamieszkiwało 1736 mieszkańców w 44 domach mieszkalnych i 5 gospodarstwach rolnych. [1] W owym okresie podjęto decyzję o budowie wielkopłytowego osiedla mieszkalnego dla 36 tysięcy mieszkańców. Budowę rozpoczęto w 1977 roku, według projektu autorstwa Kazimierza Bieńkowskiego, Andrzeja Chachaja, Zbigniewa Malinowskiego i Danuty Przyłęckiej, przez Wrocławski Kombinat Budowlany dla Spółdzielni Mieszkaniowej „Piast”. [4,5] Z projektu konkursowego zrealizowane zostały bloki mieszkalne w obszarze ograniczonym ulicami Horbaczewskiego, Balonową, Drzewieckiego i Szybowcową oraz w mniejszym zakresie w obszarze ograniczonym ulicami, Drzewieckiego, Balonową, Bystrzycką, Bajana, Szybowcową. W latach 80. w ramach akcji budowy kościoła pw. Św. Maksymiliana Kolbego we wschodniej części osiedla wzniesiono kaplicę, oraz centrum handlowe ASTRA przy ul. Horbaczewskiego, w północno-wschodniej części osiedla.

Z początkiem lat 90. ubiegłego wieku pojawiały się kolejne inwestycje: zrealizowana w latach 1989-1994 szkoła podstawowa nr 18 według projektu arch. Zbigniewa Malinowskiego, kościół pw. Miłosierdzia Bożego, dyskonty spożywcze w północnym pasie przy ul. Lotniczej, oraz przy ul. Bystrzyckiej, a także budynek biurowo-usługowy przy skrzyżowaniu ulic Lotniczej i Na Ostatnim Groszu. Z początkiem lat 90. XX wieku zaczęto zabudowywać obszar pomiędzy ulicami: Bajana, Bystrzycką, Idzikowskiego i Szybowcową. Wzniesiona w tym ostatnim obszarze deweloperska zwarta wielorodzinna zabudowa mieszkaniowa znacznie dogęściła osiedle, a powstała struktura zabudowy z małymi wnętrzami, nie nawiązywała do konkursowej wizji osiedla z lat 70. ubiegłego wieku.

\section{Charakterystyka porównawcza osiedli}

Prezentowane osiedla charakteryzuje duży potencjał mieszkaniowo-usługowy, wyrażony zarówno w liczbie mieszkańców jak i w bogatej infrastrukturze społecznej osiedla stanowiącej o atrakcyjności tych jednostek mieszkaniowych.

W obu osiedlach charakter użytkowania terenu jest podobny. (Tab. 1) Mimo wzmożonych działań inwestycyjnych w ostatnim 20-leciu (zabudowa mieszkalna i usługowa)w dalszym ciągu pozostały znaczne powierzchnie niezagospodarowane i potencjalnie możliwe do zainwestowania. (Tab. 1) Ten stan zagospodarowania i wykorzystania terenów to wynik zaniedbań i braku spójnej koncepcji kompleksowego zagospodarowania terenu przez zarządców osiedli. Krótkowzroczna polityka przestrzenna, bazująca na doraźnych korzyściach wynikających z realizacji nowych inwestycji mieszkaniowych, skutkuje pogarszaniem się standardów urbanistyczno-architektonicznych (zmniejszenie powierzchni wnętrz, terenów rekreacyjnych i zielonych itp.). Brak konsultowanych z mieszkańcami, kompleksowych działań rewitalizacyjnych, skoordynowanych z nowymi inwestycjami, prowadzi w oczywisty sposób do zubożenia walorów środowiska zamieszkania. O ile w przypadku osiedla Gądów pojawiają się drobne, głównie oddolne inicjatywy społeczne co do poprawy funkcjonowania przestrzeni w ramach tzw. Wrocławskiego Budżetu Obywatelskiego² (budowa placu zabaw, ścieżek rowerowych, Parku Leonarda Da Vinci), o tyle na Gaju działania te są symboliczne. W ostatnich latach polepszono jedynie dostęp komunikacją publiczna osiedla poprzez doprowadzenie linii tramwajowej na ul. Świeradowską.

\footnotetext{
2 W świetle projektów i inicjatyw zgłoszonych w ramach WBO, źródło: https://www.wroclaw.pl/rozmawia/ wroclawski-budzet-obywatelski.
} 

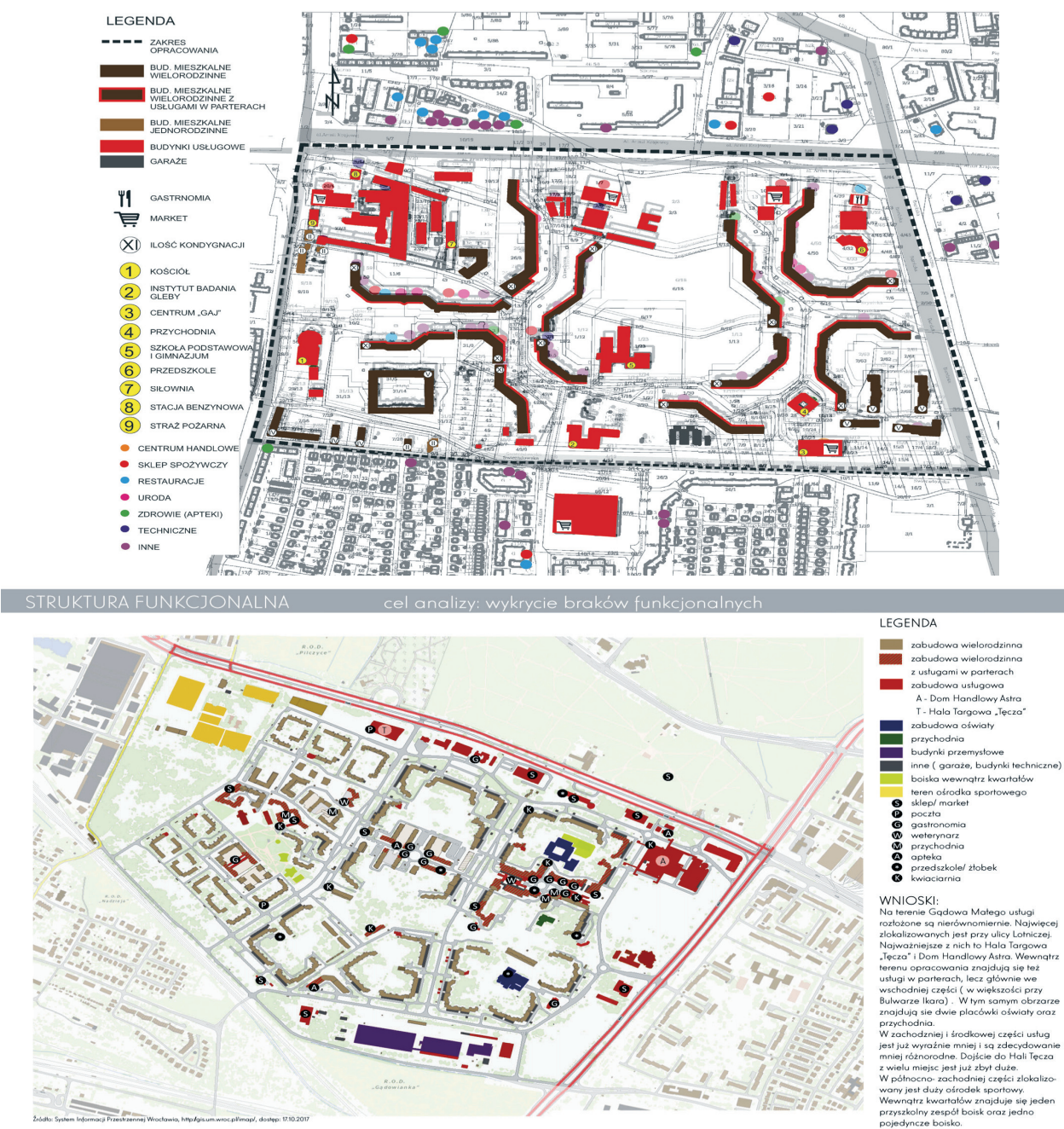

Rys. 3. Lokalizacja funkcji i usług na obszarze osiedli Gaj (po lewej) oraz Gądów (po prawej). (Źródło: opracowanie graficzne A.Wyżlic, A.Urbańska, E. Jasińska, D. Ręcławowicz, konsultacja: M. Michalski)

Infrastruktura usługowo-społeczna prezentowanych osiedli (Rys. 3) jest bogata w różnorodne funkcje i obiekty usługowo-handlowe o znaczeniu lokalnym (usługi podstawowe) jak również ponadlokalne (usługi ponadpodstawowe). Realizowana w ostatnim 20-leciu zabudowa mieszkaniowa nieznacznie zwiększyła ilość drobnego handlu w przyziemiach budynków. We wspomnianym okresie to obiekty wielkopowierzchniowe, w postaci dyskontów lub centrów handlowo-usługowych o powierzchni użytkowej powyżej $2000 \mathrm{~m}^{2}$, zdominowały inwestycje o funkcji usługowej. W osiedlu Gaj powstało ich łącznie 5, a w osiedlu Gądów 6. Drobny handel funkcjonuje głównie w przyziemiach budynków z lat 70. ubiegłego wieku. Infrastruktura społeczna, w świetle powyższego, bazuje głównie na obiektach wzniesionych w minionym wieku. 
Tabela 1. Szacunkowe zestawienie porównawcze podstawowych parametrów liczbowych i powierzchniowych dla osiedli Gaj i Gądów (opracowanie autorów)

\begin{tabular}{lcc}
\hline Dane charakterystyczne osiedli: & GAJ & GĄDÓW \\
\hline Liczba mieszkańców & 19403 & 19058 \\
\hline Powierzchnia obszaru & $150 \mathrm{ha}$ & $160 \mathrm{ha}$ \\
\hline $\begin{array}{l}\text { Powierzchnia zabudowy ogółem } \\
\text { (w tym powierzchnia zabudowy usługowej }\end{array}$ & $\begin{array}{r}231303 \mathrm{~m}^{2} \\
(23,13 \mathrm{ha})\end{array}$ & $\begin{array}{c}244347 \mathrm{~m}^{2} \\
(24,42 \mathrm{ha})\end{array}$ \\
\cline { 2 - 3 } - handel, gastronomia, rzemiosło, itd. & $18200 \mathrm{~m}^{2}$ & $23900 \mathrm{~m}^{2}$ \\
\hline $\begin{array}{l}\text { Powierzchnia terenów zielonych } \\
\text { (w tym wnętrza osiedlowe, ogródki prywatne, przestrzenie publiczne) }\end{array}$ & $\begin{array}{r}514397 \mathrm{~m}^{2} \\
\left(51,43 \mathrm{ha}^{2}\right.\end{array}$ & $\begin{array}{c}711753 \mathrm{~m}^{2} \\
\left(71,17 \mathrm{ha}^{2}\right.\end{array}$ \\
\hline $\begin{array}{l}\text { Powierzchnia terenów komunikacji } \\
\text { (w tym drogi, parkingi) }\end{array}$ & $\begin{array}{r}332400 \mathrm{~m}^{2} \\
\left(33,24 \mathrm{ha}^{2}\right.\end{array}$ & $\begin{array}{c}290500 \mathrm{~m}^{2} \\
\left(29,05 \mathrm{ha}^{2}\right.\end{array}$ \\
\hline $\begin{array}{l}\text { Powierzchnia pozostała } \\
\text { (nieużytki, tereny garaży wolnostojących, także tereny }\end{array}$ & $\begin{array}{r}421900 \mathrm{~m}^{2} \\
\left(42,19 \mathrm{ha}^{2}\right.\end{array}$ & $\begin{array}{c}353400 \mathrm{~m}^{2} \\
(35,34 \mathrm{ha})\end{array}$ \\
\hline niezagospodarowane) & &
\end{tabular}

Tabela 2. Przykładowe porównanie obrazujące wskaźnik usług powierzchni użytkowej dla osiedla Gaj i Gądów w świetle wytycznych normatywu urbanistycznego z 1974 r. (opracowanie autorów)

\begin{tabular}{lcc}
\hline $\begin{array}{l}\text { Wskaźnik usług powierzchni użytkowej } \\
\text { wg. normatywu z 1974 r. (podstawowe } \\
\begin{array}{l}\text { usługi handlowe, gastronomiczne i inne } \\
\text { nieuciążliwe dla ludności) }\end{array}\end{array}$ & $\begin{array}{c}\text { Wskaźnik } \\
\text { dla osiedla Gaj }\end{array}$ & $\begin{array}{c}\text { Wskaźnik } \\
\text { dla osiedla Gądów }\end{array}$ \\
\hline $\begin{array}{l}300-450 \mathrm{~m}^{2} / 1000 \text { mieszkańców } \\
(0,3-0,45)\end{array}$ & $\begin{array}{c}\text { Orientacyjna pow. użytkowa } \\
\text { usług ogółem: 27 000 m² } \\
\text { (wskaźnik: } 1,4)\end{array}$ & $\begin{array}{c}\text { Orientacyjna pow. użytkowa } \\
\text { usług ogółem: } 39000 \mathrm{~m}^{2} \\
\text { (wskaźnik: 2,04) }\end{array}$ \\
\hline Liczba mieszkańców & 19403 & 19058 \\
\hline
\end{tabular}

Wielkość wskaźnika funkcji usług i sklepów w stosunku do liczby mieszkańców, tak jak liczono go projektując te osiedla w latach 70-tych XX wieku, zgodnie z wytycznymi tak zwanego normatywu urbanistycznego z 1974 roku, jest znaczna. Kilkukrotnie przekracza ona wartości wskaźnika wówczas projektowane (Tab. 2). [6]

Rozkład funkcji usługowo-handlowych w osiedlu Gaj jest równomierny w całej strukturze. W przypadku Gądowa funkcje te skupiają się w północnej i północno-wschodniej części osiedla. W południowej i wschodniej części występują jedynie dyskonty spożywcze.

Tereny niezainwestowane lub nieużytkowane jako potencjalne tereny do zainwestowania obejmują w przypadku Gaju południową, południowo-wschodnią i północną część osiedla. Osiedle Gądów posiada rezerwy terenów we wschodniej, południowej i południowo-zachodniej części. Powstającą od lat 90. XX wieku zabudowa wprowadziła w osiedlach zaburzenie dotychczasowego układu urbanistycznego. W wielu wypadkach nowe układy zabudowy zdominowały przestrzeń. W wyniku realizacji indywidualnych inwestycji mieszkaniowych bez jakichkolwiek analiz urbanistycznych, w miejscach przeznaczonych w pierwotnych projektach na funkcje usługowe bądź rekreacyjno-wypoczynkowe, w analizowanych osiedlach powstał chaos przestrzenny.

\footnotetext{
3 Wg danych demograficznych Systemu Informacji Przestrzennej Wrocławia: http://geoportal.wroclaw.pl/zasoby/
} 


\section{Podsumowanie}

Wielkopłytowe osiedla mieszkaniowe, które w większości przypadków nie zostały zrealizowane w pełnym zakresie swych założeń programowych i projektowych, stanowią w strukturze przestrzennej miasta bazę dla fragmentarycznie wbudowywanej, dopełniającej lub wypełniającej nowej zabudowy mieszkaniowej i usługowej. Zaprojektowane ponad pół wieku temu osiedla swą infrastrukturą społeczną realizowały oczekiwania i potrzeby ówczesnych mieszkańców. W całym procesie przemian tych osiedli dochodzi najczęściej do anektowania tych niezabudowanych terenów dla zabudowy mieszkaniowej, chociaż w pierwotnym zamyśle były one częścią funkcji usługowych i rekreacyjno-wypoczynkowych.

W analizowanych osiedlach wolne tereny zostają zainwestowane i dochodzi do sytuacji zabudowywania terenów stanowiących przestrzenie międzyblokowe, które przewidziano w pierwotnym projekcie na tereny rekreacji i wypoczynku mieszkańców. W tym kontekście blisko 50-letnia wielorodzinna zabudowa mieszkaniowa z racji zużycia technicznego, a także zmieniających się z czasem potrzeb mieszkańców w zakresie infrastruktury społecznej, pozostaje w dalszym ciągu bez działań uwzględniających dostosowanie osiedla w wymiarze społecznym, przestrzennym i funkcjonalnym do obecnych czasów. Działania modernizacyjne polegające na termomodernizacji, ewentualnie wymianie instalacji, stanowią niewielką część potrzeb tych osiedli. W odniesieniu do wskaźnika powierzchniowego usług należy stwierdzić w świetle Tabeli 1 i Tabeli 2, że zaspokojenie w zakresie podstawowych usług handlu i gastronomii jest w zupełności wystarczające. Korekty wymaga jedynie ich lokalizacja i bezpieczny dostęp. Istniejąca infrastruktura społeczna w dalszym ciągu bazuje głównie na infrastrukturze zaprogramowanej blisko 50 lat temu, bez istotnej zmiany jakościowej, ale także ilościowej, mimo przyrostu powierzchni zabudowy mieszkaniowej, a więc także liczby mieszkańców. Tereny osiedli sklasyfikowane jako niezabudowane (niezainwestowane, nieużytkowane) stanowią jeden z głównych czynników wpływających na podatność wielkopłytowych osiedli na kompleksowe działania modernizacyjne i rewitalizacyjne. Niezrealizowane zamierzenia funkcjonalno-programowe osiedli z końca drugiej połowy XX wieku, zostawiając niezainwestowane wolne tereny, umożliwiają przeprowadzenie kompleksowych działań modernizacyjnych i rewitalizacyjnych. Działania te prowadzące do dostosowania tych osiedli do współczesnych standardów terenów mieszkalnictwa wielorodzinnego, możliwe są ze względu na występowanie na nich 20-30 procentowej rezerwy terenowej. Dla osiedla Gaj wynosi ona $28 \%$, a dla osiedla Gądów 22\%. Osiedla wielkopłytowe przy wysokim wskaźniku intensywności, stosunkowo niedużym wskaźniku powierzchni zabudowania, stwarzają duże możliwości dla realizacji nowej zabudowy i przekształceń urbanistycznych. Potencjał tych osiedli, w połączeniu z planowanymi inwestycjami przy dobrej koordynacji działań, daje duże możliwości do ich rewitalizacji. Rezerwy terenowe jako pozostałości niezrealizowanej koncepcji projektowej, stanowią atut dla lokalizacji nowych inwestycji w tych osiedlach. Jednak podatność tych osiedli na procesy rewitalizacyjne powinna być ściśle związana z kompleksowością rozwiązań funkcjonalno-przestrzennych. Rozpoczynając działania projektowe związane z założeniami modernizacji i rewitalizacji osiedli, uwzględniając potencjał osiedli, należałoby przewidzieć następujące etapy:

- Kompleksowe działania o charakterze projektowym wiążące historyczny już koncept ze współczesną zabudową (redefinicja funkcjonalno-przestrzenna).

- Społeczne inicjatywy mieszkańców osiedla i partycypacja społeczna w działaniach projektowych. 
- Modernizacja obiektów istniejących i zmiany funkcjonalno-przestrzenne uwzględniające dostosowanie programu infrastruktury społecznej do współczesnych warunków (obiekty infrastruktury społeczno-usługowej, układ komunikacyjny, problemy parkowania, dostępność dla pieszego, itd.).

- Działania poprawiające sytuację ze względu na występujące negatywne zjawiska społeczne.

\title{
Literatura
}

[1] Antkowiak Z. Stare i nowe osiedla Wrocławia. Zakład Narodowy im. Ossolińskich, Wrocław 1973.

[2] Masztalski R., Michalski. M. Role of housing reconstruction between years 2000-2014 in merging of urban structure of the north east Wrockaw. Civil and Environmental Engineering Reports 20(1) (2016) 47-57.

[3 ] 40 lat Miastoprojekt Wrocław: 1949-1989. Biuro Projektowo-Badawcze Budownictwa Ogólnego (Wrocław). Wrocław: Biuro Projektowo-Badawcze Budownictwa Ogólnego, 1989.

[4] Opacki M. Osiedle mieszkaniowe „Kosmonautów”. Encyklopedia Wrocławia, red. J. Harasimowicz, Wrocław 2001.

[5] Przyłęcka D. Nie od razu Wrocław odbudowano. Plany zagospodarowania przestrzennego, koncepcje oraz projekty urbanistyczne i architektoniczne a ich realizacja w latach 1945-1989. Wrocław 2012.

[6] Zarządzenie nr 9 Ministra Gospodarki Terenowej i Ochrony Środowiska z dnia 29 stycznia 1974 r. w sprawie wskaźników i wytycznych dla terenów mieszkaniowych w miastach. Dz. Bud. nr 2 z dnia 2 lutego 1974 r., poz. 2.

\section{Vulnerability to revitalization processes of large-plate housing estates from the second half of the twentieth century in Wroclaw}

\author{
Robert Masztalski, Marcin Michalski
}

\begin{abstract}
Department of Urban Planning and Settlement Process, University of Science and Technology, e-mail:Robert.masztalski@pwr.edu.pl,marcin.michalski.arch@pwr.edu.pl
\end{abstract}

\begin{abstract}
The article presents the problems of transformations of large-plate housing estates from the second half of the twentieth century, in view of the modern needs of their comprehensive renewal. They are subject to gradual degradation, technical consumption, and their spatial development differs from the expectations of residents, especially in the era of changing in the social model. The analytical approach to the problem will allow to show the state of the phenomenon and the predispositions, or their lack, to transformations as part of revitalization activities. The analysis of housing settlement will also allow to determine the potential range of necessary actions in this area.
\end{abstract}

Keywords: housing estate, urban transformations, revitalization. 